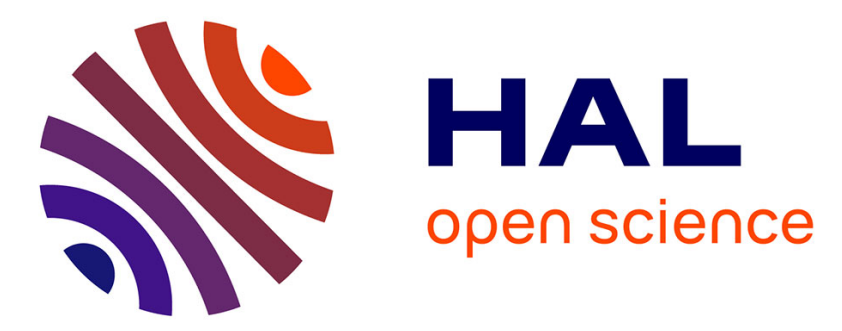

\title{
Comments on "Differentiator application in altitude control for an indoor blimp robot"
}

Mamadou Mboup, Cédric Join, Michel Fliess, Yue Wang, Gang Zheng, Denis Efimov, Wilfrid Perruquetti

\section{- To cite this version:}

Mamadou Mboup, Cédric Join, Michel Fliess, Yue Wang, Gang Zheng, et al.. Comments on "Differentiator application in altitude control for an indoor blimp robot". International Journal of Control, 2020, 93 (5), pp.1218-1219. 10.1080/00207179.2018.1500040 . hal-01832874

\section{HAL Id: hal-01832874 https://hal.inria.fr/hal-01832874}

Submitted on 9 Jul 2018

HAL is a multi-disciplinary open access archive for the deposit and dissemination of scientific research documents, whether they are published or not. The documents may come from teaching and research institutions in France or abroad, or from public or private research centers.
L'archive ouverte pluridisciplinaire HAL, est destinée au dépôt et à la diffusion de documents scientifiques de niveau recherche, publiés ou non, émanant des établissements d'enseignement et de recherche français ou étrangers, des laboratoires publics ou privés. 


\title{
Comments on "Differentiator application in altitude control for an indoor blimp robot"
}

\author{
Mboup M. ${ }^{\mathrm{a}}$, Join C. ${ }^{\mathrm{bc}}$, Fliess M. ${ }^{\mathrm{cd}}$, Wang Y.e ${ }^{\mathrm{e}}$ Zheng G. ${ }^{\mathrm{e}}$, Efimov D. ${ }^{\mathrm{e}}$, Perruquetti W. ${ }^{\mathrm{e}}$ \\ ${ }^{a}$ CReSTIC-UFR SEN, Universit de Reims Champagne Ardenne, Moulin de la Housse BP1039, 51687 Reims Cedex, France \\ ${ }^{\mathrm{b}}$ CRAN (CNRS, UMR 7039), Universit de Lorraine, BP 239, 54506 Vanduvre-ls-Nancy, France \\ ${ }^{\mathrm{c}}$ AL.I.E.N. (ALgbre pour Identification \& Estimation Numriques), 24-30 rue Lionnois, BP 60120, 54003 Nancy, France \\ ${ }^{\mathrm{d}}$ LIX(CNRS, UMR 7161), Ecole polytechnique, Palaiseau, France \\ eInria, Univ. Lille, Centrale Lille, CNRS, UMR 9189 - CRIStAL, F-59000 Lille, France
}

\section{ARTICLE HISTORY}

Compiled July 9, 2018

\section{ABSTRACT}

Comparison of several types of differentiation algorithms has been performed in the paper Wang, Zheng, Efimov, and Perruquetti (2018) with application to a robotic blimp altitude control. Unfortunately, one of the differentiation methods, the algebraic differentiator, has not been applied properly. The clarifications and the new comparison results are given in this note.

\section{Theoretical basements}

In a recent work Wang et al. (2018), the algebraic differentiators of Mboup, Join, and Fliess (2009) have been applied for the signal denoising and first-order derivative estimation of a signal $x(t)$ from its noisy measurement $y(t)=x(t)+$ noise. However, an improper application of the method resulted in unfair comparisons with other methods.

1. The algebraic estimations in equation (12) are derived from Mboup, Join, and Fliess (2007) which has been significantly improved and completed by Mboup et al. (2009), and this last reference is not cited in Wang et al. (2018). The consequence is an inappropriate application of the so-called ALIEN differentiators.

2. The algebraic differentiators admit both causal and anti-causal implementations. The estimators in equation (12) of Wang et al. (2018) seem to implement the anti-causal versions.

3. Note also that the algebraic differentiators may be parametrized to obtain derivative estimation with any prescribed delay, including zero delay. Admitting a delay allows to enhance the robustness to noise. Simple causal and delay-free versions of the estimators in equation (12) are readily given by (see Mboup et al. (2009)):

$$
\begin{aligned}
& \hat{x}_{1}(t)=2 \int_{0}^{1}(3 \tau-1) y(t-\tau T) d \tau \approx x(t) \\
& \hat{x}_{2}(t)=-\frac{12}{T} \int_{0}^{1}\left(14 \tau-15 \tau^{2}-2\right) y(t-\tau T) d \tau \approx \dot{x}(t)
\end{aligned}
$$

\section{New results of numerical experiments}

The simulations in Wang et al. (2018) are reproduced below using these causal and non delayed estimators (see figures i. and ii. where HOMD, HOSM and HG correspond to homogeneous finite-time, high-order sliding mode and high-gain differentiators, respectively). Here we set $T=0.5 \mathrm{~s}$ in (a) and $T=2.5 \mathrm{~s}$ in (b). Comparison with the corresponding figures 2 and 3 of Wang et al. (2018) shows that their conclusions need to be reconsidered in the light of the comments above. 

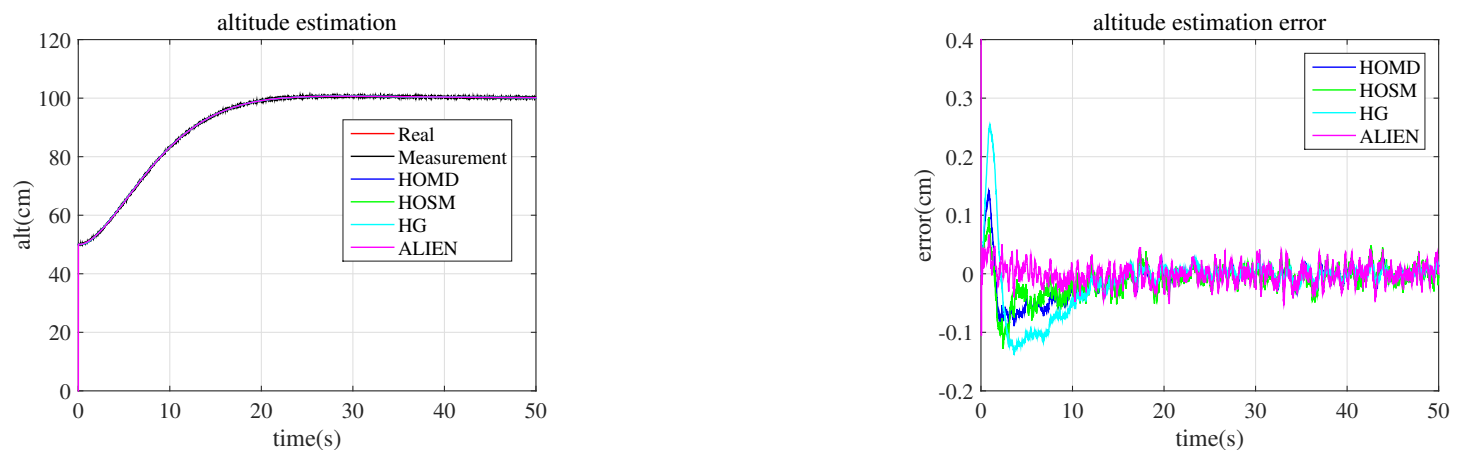

Figure i.: Signal denoising result
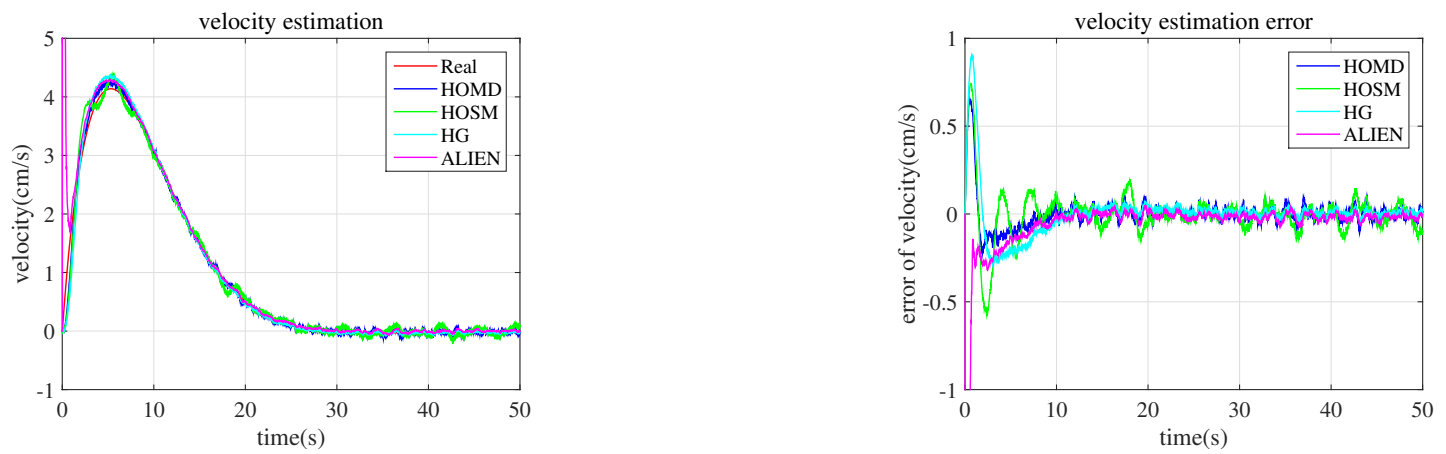

Figure ii.: First order derivative estimation result

\section{References}

Mboup, M., Join, C., \& Fliess, M. (2007). A revised look at numerical differentiation with an application to nonlinear feedback control. In 15th Mediterranean Conference on Control and Automation (MED'07). Athenes, Greece.

Mboup, M., Join, C., \& Fliess, M. (2009). Numerical differentiation with annihilators in noisy environment. Numerical Algorithms, 50(4), 439-467.

Wang, Y., Zheng, G., Efimov, D., \& Perruquetti, W. (2018). Differentiator application in altitude control for an indoor blimp robot. International Journal of Control, 0(0), 1-10. Retrieved from https://doi.org/10.1080/ 00207179.2018 .1441549 